\title{
Technical note: Could benzalkonium chloride be a suitable alternative to mercuric chloride for preservation of seawater samples?
}

\author{
J. Gloël ${ }^{1,2}$, C. Robinson ${ }^{1}$, G. H. Tilstone ${ }^{2}$, G. Tarran ${ }^{2}$, and J. Kaiser ${ }^{1}$ \\ ${ }^{1}$ Centre for Ocean and Atmospheric Sciences, School of Environmental Sciences, University of East Anglia, \\ Norwich Research Park, Norwich, UK \\ ${ }^{2}$ Plymouth Marine Laboratory, The Hoe, Plymouth, UK \\ Correspondence to: J. Kaiser (j.kaiser@uea.ac.uk)
}

Received: 10 July 2015 - Published in Ocean Sci. Discuss.: 24 August 2015

Revised: 26 November 2015 - Accepted: 30 November 2015 - Published: 7 December 2015

\begin{abstract}
Instrumental equipment unsuitable or unavailable for fieldwork as well as lack of ship space can necessitate the preservation of seawater samples prior to analysis in a shore-based laboratory. Mercuric chloride $\left(\mathrm{HgCl}_{2}\right)$ is routinely used for such preservation, but its handling and subsequent disposal incur environmental risks and significant expense. There is therefore a strong motivation to find less hazardous alternatives. Benzalkonium chloride (BAC) has been used previously as microbial inhibitor for freshwater samples. Here, we assess the use of BAC for marine samples prior to the measurement of oxygen-to-argon $\left(\mathrm{O}_{2} / \mathrm{Ar}\right) \mathrm{ra}-$ tios, as used for the determination of biological net community production. BAC at a concentration of $50 \mathrm{mg} \mathrm{dm}^{-3}$ inhibited microbial activity for at least 3 days in samples tested with chlorophyll $a$ (Chl $a$ ) concentrations up to $1 \mathrm{mg} \mathrm{m}^{-3}$. BAC concentrations of 100 and $200 \mathrm{mg} \mathrm{dm}^{-3}$ were no more effective than $50 \mathrm{mg} \mathrm{dm}^{-3}$. With fewer risks to human health and the environment, and no requirement for expensive waste disposal, BAC could be a viable alternative to $\mathrm{HgCl}_{2}$ for short-term preservation of seawater samples, but is not a replacement for $\mathrm{HgCl}_{2}$ in the case of oxygen triple isotope analysis, which requires storage over weeks to months. In any event, further tests on a case-by-case basis should be undertaken if use of BAC was considered, since its inhibitory activity may depend on concentration and composition of the microbial community.
\end{abstract}

\section{Introduction}

Marine fieldwork often requires water samples to be collected by ship and returned to a shore-based laboratory for chemical analysis. Mercuric chloride $\left(\mathrm{HgCl}_{2}\right)$ has routinely been used to inhibit microbial activity, which would otherwise alter the concentrations of oxygen $\left(\mathrm{O}_{2}\right)$, inorganic carbon (DIC) or inorganic nutrients (Emerson et al., 1991; Kattner, 1999; Dickson et al., 2007). However, the use of $\mathrm{HgCl}_{2}$ has significant disadvantages including its human toxicity, bioaccumulation, long environmental persistence and the expensive disposal of hazardous mercury-containing wastewater. $\mathrm{HgCl}_{2}$ is highly toxic to aquatic organisms, and is efficiently transferred through the food chain, accumulating in top predators such as fish (Morel et al., 1998). Consumption of mercury-contaminated fish can cause gut irritation and kidney damage in humans (Langford and Ferner, 1999). Hence, mercury-containing laboratory waste requires costly disposal to avoid it entering watercourses and wastewater treatment plants. These are strong incentives to find more environmentally benign alternatives to the use of $\mathrm{HgCl}_{2}$, in particular in remote, sensitive and pristine environments such as polar regions.

Benzalkonium chloride (alkyldimethylbenzylammonium chloride, BAC) has been used as a less hazardous alternative to $\mathrm{HgCl}_{2}$ for freshwater preservation. It is a quaternary ammonium compound, widely used as a disinfectant in hospitals and an antiseptic, preservative and algicide in the food, ophthalmic, pharmaceutical and horticultural industries (Wessels and Ingmer, 2013). BAC is classified according to EU Direc- 
Table 1. Initial conditions of time series experiments. The oxygen supersaturation is defined as $\Delta\left(\mathrm{O}_{2}\right)=c\left(\mathrm{O}_{2}\right) / c_{\mathrm{sat}}\left(\mathrm{O}_{2}\right)-1$. The biological oxygen supersaturation is defined as $\Delta\left(\mathrm{O}_{2} / \mathrm{Ar}\right)=\left[c\left(\mathrm{O}_{2}\right) / c(\mathrm{Ar})\right] /\left[c_{\mathrm{sat}}\left(\mathrm{O}_{2}\right) / c_{\mathrm{sat}}(\mathrm{Ar})\right]-1$.

\begin{tabular}{llrrrrrrrrrr}
\hline Experiment & $\begin{array}{l}\text { Sampling } \\
\text { date }\end{array}$ & $\theta /{ }^{\circ} \mathrm{C}$ & $S(\mathrm{PSS}-78)$ & $\begin{array}{r}c\left(\mathrm{NO}_{3}^{-}+\mathrm{NO}_{2}^{-}\right) / \\
\left(\mathrm{mmol} \mathrm{m}^{-3}\right)\end{array}$ & $\begin{array}{r}c\left(\mathrm{SiO}_{4}^{4-}\right) / \\
\left(\mathrm{mmol} \mathrm{m}^{-3}\right)\end{array}$ & $\begin{array}{r}c\left(\mathrm{PO}_{4}^{3-}\right) / \\
\left(\mathrm{mmol} \mathrm{m}^{-3}\right)\end{array}$ & $\begin{array}{r}c(\mathrm{Chl} a) \\
\left(\mathrm{mg} \mathrm{m}^{-3}\right)\end{array}$ & $\begin{array}{r}c\left(\mathrm{O}_{2}\right) / \\
\left(\mathrm{mmol} \mathrm{m}^{-3}\right)\end{array}$ & $\begin{array}{r}\Delta\left(\mathrm{O}_{2}\right) \\
\mathrm{Cell} \mathrm{number}\end{array}$ & $\begin{array}{r}\Delta\left(\mathrm{O}_{2} / \mathrm{Ar}\right) \\
\mathrm{concentration} \mathrm{cm}^{-3}\end{array}$ \\
\hline TS1 & $08 / 02 / 2010$ & 8.2 & 34.90 & 8.6 & 4.8 & 0.6 & 0.4 & 292.4 & $-0.4 \%$ & $-0.2 \%$ & not analysed \\
TS2 & $19 / 04 / 2010$ & 9.0 & 35.06 & 3.3 & 0.5 & 0.3 & 1.0 & 31.5 & $+8.1 \%$ & $+6.7 \%$ & $6.9 \times 10^{5}$ \\
TS3 & $17 / 05 / 2010$ & 10.2 & 35.04 & 0.1 & 0.4 & 0.1 & 0.6 & 315.4 & $+12.3 \%$ & $+9.5 \%$ & $6.8 \times 10^{5}$ \\
\hline
\end{tabular}

tives 67/548/EEC and 1999/45/EC as harmful when in contact with skin and if swallowed and very toxic to aquatic organisms. Release to the environment should be avoided; however, the preservative effect of BAC can be neutralised by the emulsifiers polysorbate 80 and lecithin (Block, 2001). Kuo (1998) used BAC to preserve freshwater samples for carboxylic acid analysis and achieved effective preservation for up to 30 days using a concentration of $30-50 \mathrm{mg} \mathrm{dm}^{-3}$.

$\mathrm{HgCl}_{2}$ and BAC have different mechanisms of inhibiting microbial activity. Mercury binds to the thiol groups of amino acids and therefore inhibits enzyme activity (Langford and Ferner, 1999). BAC is a cationic surfactant that physically permeates the cytoplasmic membrane causing its disruption, release of cytoplasmic constituents, precipitation of cell contents and cell death (Wessels and Ingmer, 2013; Ferreira et al., 2011).

The aim of this study was to test if BAC was as effective as $\mathrm{HgCl}_{2}$ in preventing microbial activity. The target application was the preservation of marine samples for measurement of $\mathrm{O}_{2} / \mathrm{Ar}$ ratios and oxygen triple isotopes used to determine net and gross community production (Craig and Hayward, 1987; Quay et al., 2012). Measurements of $\mathrm{O}_{2} / \mathrm{Ar}$ ratios with membrane inlet mass spectrometry (MIMS) are usually made by immediate and continuous analysis of seawater from the underway sampling system on scientific research ships (Kaiser et al., 2005; Hamme et al., 2012). However, sampling in coastal areas may be conducted on small vessels or ships of opportunity without mass-spectrometric facilities to analyse samples on board. Similarly, laboratory studies of $\mathrm{O}_{2}$ respiration or production may require arresting biological activity at defined time points and subsequent batch analysis of all samples together. These discrete samples have to be preserved until analysis, usually within a few days, and $\mathrm{HgCl}_{2}$ has previously been used for this purpose (Holtappels et al., 2014; Kana et al., 2006). In contrast, weeks, months and, occasionally, years (Hendricks et al., 2005) may elapse before oxygen triple isotope samples are analysed. The effectiveness of BAC as an alternative preservative to halt microbial production or consumption of $\mathrm{O}_{2}$ in seawater samples was therefore assessed.

\section{Experimental methods}

Surface water $(5 \mathrm{~m})$ was collected at around 08:30 local time from the Western English Channel Ob- servatory time series station L4 (Smyth et al., 2010), approximately $13 \mathrm{~km}$ southwest of Plymouth, United Kingdom $\left(50^{\circ} 15.00^{\prime} \mathrm{N}, 4^{\circ} 13.02^{\prime} \mathrm{W}\right.$; http://www.westernchannelobservatory.org.uk/). Samples were maintained in darkness at in situ temperature $\left(8-10^{\circ} \mathrm{C}\right)$ in $30 \mathrm{dm}^{-3}$ carboys whilst being transported to the shore-based laboratory within $3 \mathrm{~h}$ of collection.

An initial experiment was conducted to assess whether the addition of $\mathrm{HgCl}_{2}$ or BAC solution interfered with the analysis of $\mathrm{O}_{2} / \mathrm{Ar}$ ratios by MIMS. The seawater sample was distributed into six replicate $0.5 \mathrm{dm}^{3}$ glass bottles with ground glass stoppers. Two samples each were treated with $\mathrm{HgCl}_{2}$, $\mathrm{BAC}$ or left untreated. The bottle stopper was replaced ensuring no headspace remained and secured with rubber bands (Dickson et al., 2007). For the samples treated with $\mathrm{HgCl}_{2}$, $0.2 \mathrm{~cm}^{3}$ of saturated $\mathrm{HgCl}_{2}$ solution $\left(76 \mathrm{~g} \mathrm{dm}^{-3}\right)$, corresponding to $15 \mathrm{mg} \mathrm{HgCl}_{2}$, was added to the sample, giving a final concentration of $30 \mathrm{mg} \mathrm{dm}^{-3}$. This is the recommended concentration and addition volume $(0.02-0.05 \%$ of the sample volume) for inorganic nutrients (Kirkwood, 1992), DIC and total alkalinity (TA) samples (Dickson et al., 2007). For the samples treated with BAC, $0.25 \mathrm{~cm}^{3}$ of a $1 \mathrm{~g} \mathrm{dm}^{-3}$ solution was added to the sample, giving a final concentration of $50 \mathrm{mg} \mathrm{dm}^{-3}$ BAC as suggested by Kuo (1998). The samples were analysed immediately using MIMS.

The first time series experiment (TS1, see Table 1 for an overview of the water composition at the time of sampling) was conducted with water collected from L4 in February 2010 to test whether BAC was as efficient as $\mathrm{HgCl}_{2}$ at preserving samples for 7 days. Replicate $0.5 \mathrm{dm}^{3}$ samples were prepared as described above and one-third each treated with $\mathrm{HgCl}_{2}$, BAC or left untreated. The bottles were stored underwater in the dark at $15^{\circ} \mathrm{C}$. Samples from each treatment were analysed immediately, and then again after 1, 2 and 7 days.

A second time series experiment (TS2) was undertaken in April 2010 at the time of the spring phytoplankton bloom when chlorophyll $a$ concentrations were higher. Again, replicate $0.5 \mathrm{dm}^{3}$ samples were prepared, treated and stored as described above. Samples from each treatment $\left(\mathrm{HgCl}_{2}, \mathrm{BAC}\right.$, no addition) were analysed immediately and after 1,3 and 8 days.

Finally, a third time series experiment (TS3) was undertaken in May 2010 to test the efficiency of increased concentrations of $\mathrm{BAC}\left(\mathrm{BAC} \times 2: 100 \mathrm{mg} \mathrm{dm}^{-3}\right.$ and $\mathrm{BAC} \times 4$ : $200 \mathrm{mg} \mathrm{dm}^{-3}$ ) over a 17-day period. Again, replicate $0.5 \mathrm{dm}^{3}$ 
samples were prepared, treated and stored as described above. Treatments were $\mathrm{HgCl}_{2}, \mathrm{BAC}, \mathrm{BAC} \times 2, \mathrm{BAC} \times 4$ and no addition, and samples of each of the treatments were analysed immediately and after 2, 4 and 17 days.

\section{$2.1 \mathrm{O}_{2} /$ Ar ratios}

$\mathrm{O}_{2} / \mathrm{Ar}$ ratios were analysed using MIMS (Kaiser et al., 2005). The system was operated continuously: when not running a seawater sample, Milli-Q water was circulated. Sample water was pumped through a Teflon AF membrane (Random Technologies) using a peristaltic pump. The membrane was held under vacuum at a constant temperature of $15^{\circ} \mathrm{C}$ in a water bath. The gas from the membrane then flowed into a quadrupole mass spectrometer (Pfeiffer Vacuum Prisma). Its flight tube was held at $70^{\circ} \mathrm{C}$ using heating tape. The flow of water was maintained at $(38 \pm 1) \mathrm{cm}^{3} \mathrm{~min}^{-1}$. Equilibrated water standards were prepared containing artificial seawater of salinity 35.1 at $15^{\circ} \mathrm{C}$, and were run before and after the samples to account for any drift in the MIMS output over the approximately $2 \mathrm{~h}$ taken for analysis of all samples and standards. Results are reported as biological oxygen supersaturations, $\Delta\left(\mathrm{O}_{2} / \mathrm{Ar}\right)$, with respect to air-equilibrated water (Kaiser et al., 2005). Drift was generally $<0.1$, and $0.15 \%$ at most. Possible reasons for a drift would be a temperature change in the laboratory or a change of water flow. Each sample was analysed for $7 \mathrm{~min}$. The repeatability based on the analysis of duplicate samples was $0.02 \%$, on a given day. Any change greater than 2 times the repeatability (i.e. $0.04 \%$ ) is considered to be a statistically significant difference for samples analysed on a given day.

However, for comparison of samples analysed on different days of the time series, the calibration uncertainty needs to be taken into account, which is $0.2 \%$ (error bars in Figs. 1-3). Any change greater than 2 times this uncertainty (i.e. $0.4 \%$ ) with respect to the initial $\mathrm{O}_{2} / \mathrm{Ar}$ ratio is considered to be statistically significant.

Direct comparison of $\mathrm{BAC}$-treated and $\mathrm{HgCl}_{2}$-treated samples after the same storage period therefore gives the most reliable indication of the relative efficacy of both preservatives.

\subsection{Chlorophyll $a$ concentration}

Water samples $\left(0.1 \mathrm{dm}^{3}\right)$ were filtered through $25 \mathrm{~mm}$ (nominal pore size $0.7 \mu \mathrm{m})$ glass-fibre filters $(\mathrm{GF} / \mathrm{F})$ and extracted in acetone/water (volume ratio 9:1) overnight at $4{ }^{\circ} \mathrm{C}$. Chlorophyll $a$ ( $\mathrm{Chl} a$ ) concentrations were measured using a Turner fluorometer (Welschmeyer, 1994).

\subsection{Heterotrophic bacteria}

Heterotrophic bacterial number concentration was determined by analytical flow cytometry. Scattered light and fluorescence intensity were measured on a FACSort flow cytometer (Becton Dickinson, Oxford, UK) with log amplifica-

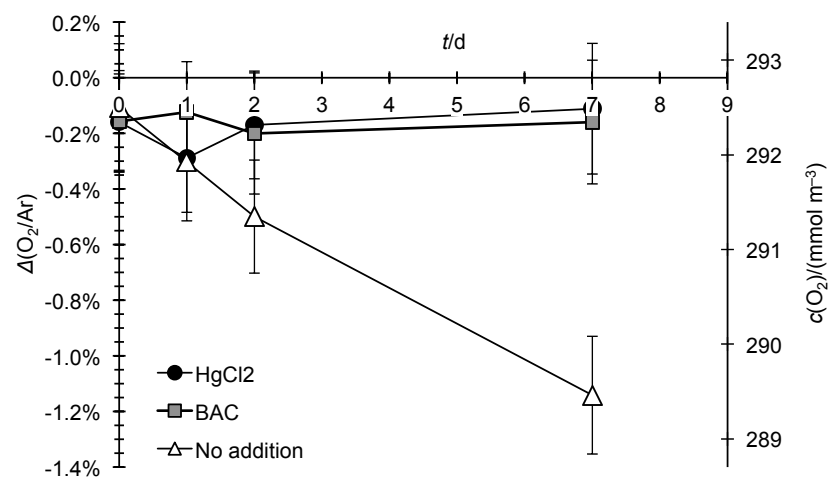

Figure 1. Biological oxygen supersaturation $\Delta\left(\mathrm{O}_{2} / \mathrm{Ar}\right)$ and corresponding oxygen concentration during TS1 (February 2010), for samples without treatment (white triangle), BAC-treated (grey square) and $\mathrm{HgCl}_{2}$-treated (black circle). Error bars include the dayto-day calibration uncertainty.

tion on a 4-decade scale with 1024-channel resolution (Tarran et al., 2006). Samples were analysed for $1 \mathrm{~min}$ at a flow rate of $0.055 \mathrm{~cm}^{3} \mathrm{~min}^{-1}$, determined using Beckman Coulter Flowset fluorospheres in a $1: 10$ dilution. Each $0.5 \mathrm{~cm}^{3} \mathrm{sam}-$ ple was stained for $1 \mathrm{~h}$ with SYBR Green mixed with potassium citrate solution (Marie et al., 1997) prior to analysis. Data were analysed with the program WinMDI 2.9 (Joseph Trotter, SCRIPPS Research Institute). We assumed a coefficient of variation (standard deviation/mean) for bacterial number concentration of $5 \%$ (Šantić et al., 2007).

\section{Results and discussion}

$\mathrm{HgCl}_{2}$ is known to be a suitable preservative for seawater samples prior to mass spectrometric measurement of dissolved $\mathrm{O}_{2}$ (e.g. Hendricks et al., 2005), whereas BAC is not routinely used in this way. We therefore tested whether the addition of $\mathrm{BAC}$ altered the seawater $\mathrm{O}_{2}$ concentration or interfered with the MIMS analysis for $\mathrm{O}_{2} / \mathrm{Ar} . \Delta\left(\mathrm{O}_{2} / \mathrm{Ar}\right)$ of two replicate samples to which BAC had been added was not significantly different from $\Delta\left(\mathrm{O}_{2} / \mathrm{Ar}\right)$ of two replicate samples to which $\mathrm{HgCl}_{2}$ had been added. Therefore, BAC did not interfere with the accurate determination of $\mathrm{O}_{2} / \mathrm{Ar}$.

The Chl $a$ concentration in TS1 samples was $0.4 \mathrm{mg} \mathrm{m}^{-3}$ (Table 1). $\Delta\left(\mathrm{O}_{2} / \mathrm{Ar}\right)$ values in replicate samples to which $\mathrm{BAC}$ was added were not significantly different from samples to which $\mathrm{HgCl}_{2}$ was added, and both stayed constant over the seven days of the experiment (Fig. 1). However, $\Delta\left(\mathrm{O}_{2} / \mathrm{Ar}\right)$ of untreated samples decreased by $(0.4 \pm 0.2) \%$ after 2 days and by $(1.0 \pm 0.2) \%$ after 7 days. This suggests that BAC was as effective as $\mathrm{HgCl}_{2}$ at preserving the $\mathrm{O}_{2}$ concentration in these particular low $\mathrm{Chl} a$ concentration-seawater samples for up to 7 days.

The Chl $a$ concentration in TS2 samples was $1.0 \mathrm{mg} \mathrm{m}^{-3}$. Heterotrophic bacterial number concentration was $6.9 \times$ 


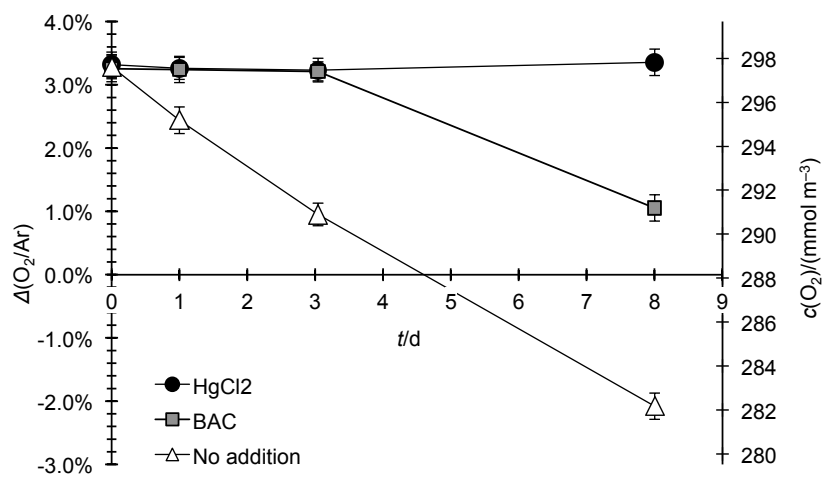

Figure 2. Biological oxygen supersaturation $\Delta\left(\mathrm{O}_{2} / \mathrm{Ar}\right)$ and corresponding oxygen concentration during TS2 (April 2010), for samples without treatment (white triangle), BAC-treated (grey square) and $\mathrm{HgCl}_{2}$-treated (black circle). Error bars include the day-to-day calibration uncertainty.

$10^{5} \mathrm{~cm}^{-3} \cdot \Delta\left(\mathrm{O}_{2} / \mathrm{Ar}\right)$ of the untreated samples decreased by $(0.8 \pm 0.2) \%$ after 1 day and by $(5.2 \pm 0.2) \%$ after 8 days of storage, indicating $\mathrm{O}_{2}$ consumption in these samples (Fig. 2). $\Delta\left(\mathrm{O}_{2} / \mathrm{Ar}\right)$ of $\mathrm{HgCl}_{2}$-treated samples remained constant over the 8 days. $\Delta\left(\mathrm{O}_{2} / \mathrm{Ar}\right)$ of BAC-treated samples remained constant and not significantly different from $\mathrm{HgCl}_{2}$-treated samples for 3 days, but decreased by $(2.3 \pm 0.2) \%$ after 8 days and were at that time $(2.35 \pm 0.03) \%$ lower $(p<0.001$, two-tailed $t$ test) than the $\mathrm{HgCl}_{2}$-treated samples. This suggests that the time over which BAC is effective at preserving seawater samples decreases with increasing $\mathrm{Chl} a$ concentration.

The Chl $a$ concentration in TS3 samples was $0.6 \mathrm{mg} \mathrm{m}^{-3}$. Heterotrophic bacterial number concentration was $6.8 \times$ $10^{5} \mathrm{~cm}^{-3} \cdot \Delta\left(\mathrm{O}_{2} / \mathrm{Ar}\right)$ showed similar results to TS2, with a $(2.6 \pm 0.2) \%$ decrease of the $\Delta\left(\mathrm{O}_{2} / \mathrm{Ar}\right)$ of the untreated sample after 4 days and a $(7.7 \pm 0.2) \%$ decrease after 17 days (Fig. 3). $\Delta\left(\mathrm{O}_{2} / \mathrm{Ar}\right)$ of samples containing BAC remained constant and not significantly different from the samples containing $\mathrm{HgCl}_{2}$ for 4 days; by 17 days they were $(0.34 \pm 0.03) \%$ lower $(p<0.01)$ than the samples containing $\mathrm{HgCl}_{2}$ (Fig. 3). $\mathrm{BAC} \times 2\left(100 \mathrm{mg} \mathrm{dm}^{-3}\right)$ and $\mathrm{BAC} \times 4$ $\left(200 \mathrm{~m} \mathrm{dm}^{-3}\right)$ were no more effective as preservatives than BAC $\left(50 \mathrm{mg} \mathrm{dm}^{-3}\right)$, and there was no significant difference in the temporal evolution of $\Delta\left(\mathrm{O}_{2} / \mathrm{Ar}\right)$ in samples containing $\mathrm{BAC}, \mathrm{BAC} \times 2, \mathrm{BAC} \times 4 . \Delta\left(\mathrm{O}_{2} / \mathrm{Ar}\right)$ values of the $\mathrm{BAC} \times 4$ samples were $(0.19 \pm 0.03) \%$ lower than the other samples throughout the time series. This decrease appears even at time zero. This may be partially due to a dilution effect caused by the larger volume of BAC solution used, but in order to explain the initial $0.2 \%$ drop in $c\left(\mathrm{O}_{2}\right)$, the oxygen concentration of the BAC solution would have to have been near 0 , which is unlikely. We therefore cannot fully explain the decrease in oxygen concentration associated with the BAC $\times 4$ addition. However, this does not invalidate any of our conclusions because, after this initial drop, the $\mathrm{BAC} \times 4$

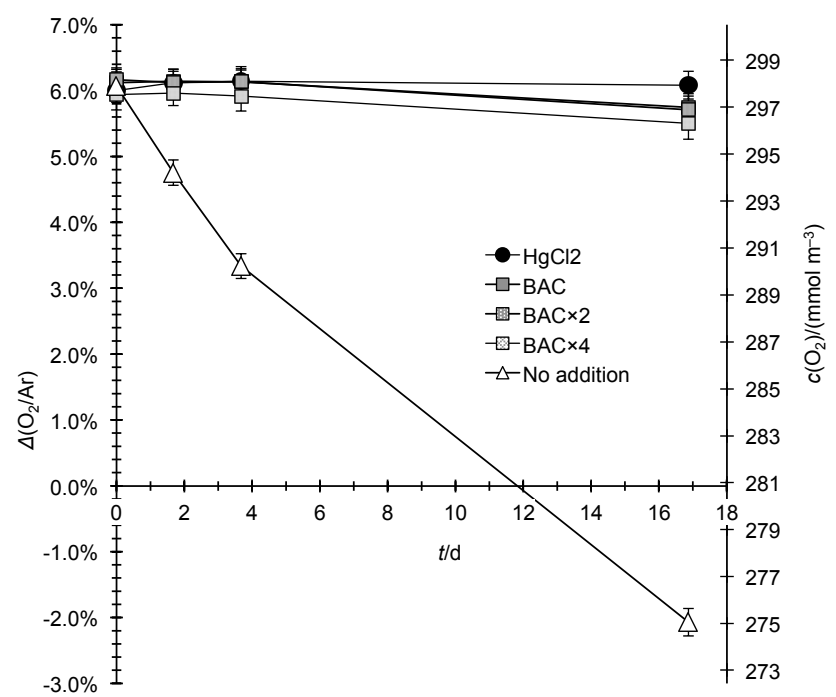

Figure 3. Biological oxygen supersaturation $\Delta\left(\mathrm{O}_{2} / \mathrm{Ar}\right)$ and corresponding oxygen concentration during TS3 (May 2010), for samples without treatment (white triangle) and treated with BAC (grey square), $\mathrm{BAC} \times 2$ (dark grey stippled square), BAC $\times 4$ (light grey stippled square) or $\mathrm{HgCl}_{2}$ (black circle). Error bars include the dayto-day calibration uncertainty.

time series shows the same relative trend with respect to the initial concentration as the $\mathrm{BAC}$ and $\mathrm{BAC} \times 2$ time series.

Analysis of green fluorescence and side scatter determined by flow cytometry during TS3 enabled an assessment of the effect of $\mathrm{HgCl}_{2}$ and $\mathrm{BAC}$ on heterotrophic bacterial number concentration (Fig. 4). The bacterial cell number concentration in the sample which had not been treated increased from 7.2 to $11.2 \times 10^{5} \mathrm{~cm}^{-3}$ in the first 2 days, before decreasing to $2.4 \times 10^{5} \mathrm{~cm}^{-3}$ after 17 days, presumably due to a combination of grazing and nutrient limitation. Number densities in samples treated with $\mathrm{HgCl}_{2}$ remained relatively constant, from $6.5 \times 10^{5} \mathrm{~cm}^{-3}$ at time $0-5.2 \times 10^{5} \mathrm{~cm}^{-3}$ on day 17. However, since $\Delta\left(\mathrm{O}_{2} /\right.$ Ar) barely changed (Fig. 3$)$, the cells must have been inactive or dead. The number concentration in samples treated with BAC declined immediately on addition of BAC to $1.5 \times 10^{5} \mathrm{~cm}^{-3}$, decreasing to less than $0.2 \times 10^{5} \mathrm{~cm}^{-3}$ within 2 days and to less than $0.1 \times 10^{5} \mathrm{~cm}^{-3}$ after 17 days. This is consistent with the mode of toxicity of BAC: disruption of the cell membrane and release of the cell contents. However, it is not consistent with the decrease in $\Delta\left(\mathrm{O}_{2} / \mathrm{Ar}\right)$ seen after 17 days in the BAC-treated samples (Fig. 3). BAC is not effective against bacterial spores (Block, 2001), so it is possible that viable bacterial cells in the sample were killed immediately, leaving spores to become viable after a few days. BAC can be a carbon and energy source for some bacteria (Oh et al., 2013) and acquired bacterial resistance to BAC has also been recorded (Wessels and Ingmer, 2013). However, if any of these suggestions were the case, then the bacterial number concentration would have increased after day 4 alongside the decrease in $\Delta\left(\mathrm{O}_{2} / \mathrm{Ar}\right)$. An 


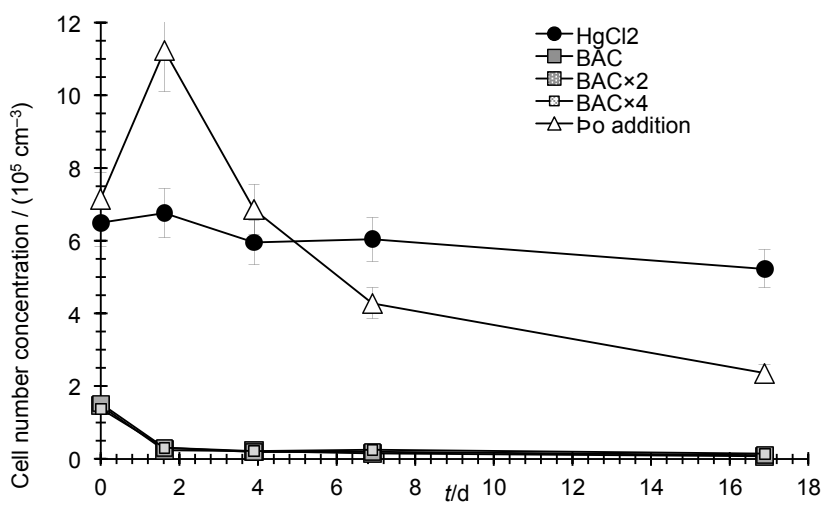

Figure 4. Number concentration of heterotrophic bacteria in samples collected during TS3 treated with different concentrations of $\mathrm{BAC}, \mathrm{HgCl}_{2}$ and with no addition of preservative.

alternative possibility is that the low bacterial number concentration derived from flow cytometric analysis is due to interference between BAC and the SYBR Green stain. SYBR Green staining is not recommended for use with surfactants (http://tools.lifetechnologies.com/content/sfs/manuals/ td004.pdf); hence bacterial cells could have been inhibited by BAC for up to 4 days, but then recovered to continue to consume $\mathrm{O}_{2}$. This would reduce $\Delta\left(\mathrm{O}_{2} / \mathrm{Ar}\right)$, but the cells would not be counted by the staining and counting procedure. It is also possible that the decrease in $\Delta\left(\mathrm{O}_{2} / \mathrm{Ar}\right)$ after 4 days was due to the growth of microzooplankton rather than bacteria. Characterisation of the mode of toxicity of BAC on each component of the biological community is beyond the scope of this study; rather, we focussed on ascertaining the timescale over which seawater samples could be preserved prior to analysis.

\section{Conclusions}

Samples for accurate determination of $\mathrm{O}_{2} / \mathrm{Ar}$ ratios, if not analysed immediately after collection, need to be preserved with an inhibitor of microbial activity. $\mathrm{HgCl}_{2}$ reliably preserved samples for the maximum experimental time of 17 days. BAC was found to be an effective preservative for at least 3 days, for seawater samples containing Chl $a$ concentrations of up to $1 \mathrm{mg} \mathrm{m}^{-3}$. Therefore, BAC, which poses fewer risks to human health and the environment and does not require expensive waste disposal, could be used as a viable alternative to $\mathrm{HgCl}_{2}$ for short-term preservation of samples prior to MIMS analysis. However, it is not effective as a replacement for $\mathrm{HgCl}_{2}$ in oxygen triple isotope samples, which require longer-term storage over weeks to months, or even years. Any respiration that is not completely inhibited by the preservative also changes nutrient and dissolved organic and inorganic carbon concentrations, following the stoichiometry of the dissolved and particulate organic matter pools with respect to oxygen (Anderson and Sarmiento,
1994), which would mean that BAC is not suitable for these parameters either. We would also recommend further tests with $\mathrm{BAC}$ on a case-by-case basis because its mode of action and efficacy might be affected by cross-reactions with other seawater constituents, especially under higher $\mathrm{Chl} a$ concentrations.

Acknowledgements. We thank the crew of RV Plymouth Quest for help with sampling at L4 and Morvan Barnes (PML) for Chl $a$ concentration analysis. This work was supported by NERC SOFI studentship NE/F012608/1, Royal Society Research Merit Award WM052632 and EU FP7 contract no. 07-027-FR-ISECA (Information System on the Eutrophication of our Coastal Seas, ISECA, INTERREG IVA 2 Mers Seas Zeeen Cross-border Cooperation Programme 2007-2013).

Edited by: M. Hoppema

\section{References}

Anderson, L. A. and Sarmiento, J. L.: Redfield ratios of remineralization determined by nutrient data analysis, Global Biogeochem. Cy., 8, 65-80, doi:10.1029/93GB03318, 1994.

Block, S. S.: Disinfection, Sterilization and Preservation, Lippincott Williams \& Wilkins, Philadelphia, USA, 2001.

Craig, H. and Hayward, T.: Oxygen supersaturation in the ocean: biological versus physical contributions, Science, 235, 199-202, 1987.

Dickson, A. G., Sabine, C. L., and Christian, J. R.: Guide to best practices for ocean $\mathrm{CO}_{2}$ measurements, PICES Special Publication 3, IOCCP Report No. 8, 191 pp., 2007.

Emerson, S., Quay, P., Stump, C., Wilbur, D., and Know, M.: $\mathrm{O}_{2}$, Ar, $\mathrm{N}_{2}$, and ${ }^{222} \mathrm{Rn}$ in surface waters of the subarctic ocean: net biological $\mathrm{O}_{2}$ production, Global Biogeochem. Cy., 5, 49-69, 1991.

Ferreira, C., Pereira, A. M., Pereira, M. C., Melo, L. F., and Simões, M.: Physiological changes induced by the quaternary ammonium compound benzyldimethyldodecylammonium chloride on Pseudomonas fluorescens, J. Antimicrob. Chemoth., 66, 1036-1043, doi:10.1093/jac/dkr028, 2011.

Hamme, R. C., Cassar, N., Lance, V. P., Vaillancourt, R. D., Bender, M. L., Strutton, P. G., Moore, T. S., DeGrandpre, M. D., Sabine, C. L., Ho, D. T., and Hargreaves, B. R.: Dissolved $\mathrm{O}_{2} / \mathrm{Ar}$ and other methods reveal rapid changes in productivity during a Lagrangian experiment in the Southern Ocean, J. Geophys. Res., 117, C00F12, doi:10.1029/2011jc007046, 2012.

Hendricks, M. B., Bender, M. L., Barnett, B. A., Strutton, P., and Chavez, F. P.: The triple oxygen isotope composition of dissolved $\mathrm{O}_{2}$ in the equatorial Pacific: a tracer of mixing, production, and respiration, J. Geophys. Res., 110, C12021, doi:10.1029/2004JC002735, 2005.

Holtappels, M., Tiano, L., Kalvelage, T., Lavik, G., Revsbech, N. P., and Kuypers, M. M. M.: Aquatic respiration rate measurements at low oxygen concentrations, PLoS ONE, 9, e89369, doi:10.1371/journal.pone.0089369, 2014.

Kaiser, J., Reuer, M. K., Barnett, B., and Bender, M. L.: Marine productivity estimates from continuous oxygen/argon ratio mea- 
surements by shipboard membrane inlet mass spectrometry, Geophys. Res. Lett., 32, L19605, doi:10.1029/2005GL023459, 2005.

Kana, T., Cornwell, J., and Zhong, L.: Determination of denitrification in the Chesapeake Bay from measurements of $\mathrm{N}_{2}$ accumulation in bottom water, Estuar. Coast., 29, 222-231, doi:10.1007/BF02781991, 2006.

Kattner, G.: Storage of dissolved inorganic nutrients in seawater: poisoning with mercuric chloride, Mar. Chem., 67, 61-66, 1999.

Kirkwood, D. S.: Stability of solutions of nutrient salts during storage, Mar. Chem., 38, 151-164, doi:10.1016/03044203(92)90032-6, 1992.

Kuo, C.-Y.: Improved application of ion chromatographic determination of carboxylic acids in ozonated drinking water, J. Chromatogr. A, 804, 265-272, 1998.

Langford, N. and Ferner, R.: Toxicity of mercury, J. Hum. Hypertens., 13, 651-656, 1999.

Marie, D., Partensky, F., Jacquet, S., and Vaulot, D.: Enumeration and cell cycle analysis of natural populations of marine picoplankton by flow cytometry using the nucleic acid stain SYBR Green I, Appl. Environ. Microbiol., 63, 186-193, 1997.

Morel, F. M. M., Kraepiel, A. M. L., and Amyot, M.: The chemical cycle and bioaccumulation of mercury, Annu. Rev. Ecol. Syst., 29, 543-566, doi:10.1146/annurev.ecolsys.29.1.543, 1998.

Oh, S., Tandukar, M., Pavlostathis, S. G., Chain, P. S. G., and Konstantinidis, K. T.: Microbial community adaptation to quaternary ammonium biocides as revealed by metagenomics, Environ. Microbiol., 15, 2850-2864, doi:10.1111/1462-2920.12154, 2013.
Quay, P., Stutsman, J., and Steinhoff, T.: Primary production and carbon export rates across the subpolar N. Atlantic Ocean basin based on triple oxygen isotope and dissolved $\mathrm{O}_{2}$ and Ar gas measurements, Global Biogeochem. Cy., 26, GB2003, doi:10.1029/2010gb004003, 2012.

Šantić, D., Krstulović, N., and Šolić, M.: Comparison of flow cytometric and epifluorescent counting methods for marine heterotrophic bacteria, Acta Adriat., 48, 107-114, 2007.

Smyth, T. J., Fishwick, J. R., AL-Moosawi, L., Cummings, D. G., Harris, C., Kitidis, V., Rees, A., Martinez-Vicente, V., and Woodward, E. M. S.: A broad spatio-temporal view of the Western English Channel observatory, J. Plankton Res., 32, 585-601, doi:10.1093/plankt/fbp128, 2010.

Tarran, G. A., Heywood, J. L., and Zubkov, M. V.: Latitudinal changes in the standing stocks of nano- and picoeukaryotic phytoplankton in the Atlantic Ocean, Deep-Sea Res. Pt. II, 53, 15161529, 2006.

Welschmeyer, N. A.: Fluorometric analysis of chlorophyll $a$ in the presence of chlorophyll $b$ and pheopigments, Limnol. Oceanogr., 39, 1985-1992, doi:10.4319/lo.1994.39.8.1985, 1994.

Wessels, S. and Ingmer, H.: Modes of action of three disinfectant active substances: a review, Regul. Toxicol. Pharm., 67, 456-467, doi:10.1016/j.yrtph.2013.09.006, 2013. 